\begin{abstract}
Yellowtail jack (Seriola dorsalis) are highly prized game fish within the Southern California Bight (SCB). Despite the popularity of this species, life history and demographic information for it is scant, with one previous biological examination and no population assessments. For the study described here, we used modern analytical techniques, updating historical analyses, applied stable isotope analysis to investigate ontogenetic habitat shifts, and established a novel relationship of opercular length to fork length. We sampled 256 yellowtail jack across the SCB and Baja California, Mexico, during 2014-2016. Sizes ranged from 22.7 to $162.7 \mathrm{~cm}$ fork length with estimated ages of 1-22 years. Body size affected diet, with larger fish consuming a greater diversity of prey. Across all samples, we recorded 19 prey species; the pelagic red crab (Pleuroncodes planipes), found in $23 \%$ of stomachs, was most prevalent. Coastal pelagic fish species, detected in $62 \%$ of stomachs, made up the most common group. Larger yellowtail jack were more $\delta^{15} \mathrm{~N}$ enriched, indicating increasing trophic position, and $\delta^{13} \mathrm{C}$ levels signify an inshore-offshore habitat transition after maturity. Our results define yellowtail jack from the SCB and Baja California as one contiguous population with consistent ontogenetic variation in diet, trophic position, and growth rate. However, fish from remote areas were older and larger, perhaps indicating de facto fishing refuges.
\end{abstract}

Manuscript submitted 11 July 2019. Manuscript accepted 19 May 2020. Fish. Bull. 118:157-170 (2020). Online publication date: 3 June 2020. doi: 10.7755/FB.118.2.5

The views and opinions expressed or implied in this article are those of the author (or authors) and do not necessarily reflect the position of the National Marine Fisheries Service, NOAA.

\title{
Revisiting the life history of yellowtail jack (Seriola dorsalis) in the Southern California Bight: new evidence for ontogenetic habitat shifts and regional differences in a changing environment
}

\author{
Noah Ben-Aderet (contact author) \\ Erin M. Johnston \\ Richard Cravey \\ Stuart A. Sandin \\ Email address for contact author: nbenader@ucsd.edu \\ Center for Marine Biodiversity and Conservation \\ Scripps Institution of Oceanography \\ University of California, San Diego \\ 9500 Gilman Drive \\ La Jolla, California 92083-0202 \\ Present address for contact author: Fisheries Resources Division \\ Southwest Fisheries Science Center \\ National Marine Fisheries Service, NOAA \\ 8901 La Jolla Shores Drive \\ La Jolla, California 92037
}

Across their global distribution, carangid fish species are highly prized as both game and food fish. Prominent among this group are the several species in the genus Seriola, whose members are known commonly as yellowtail, amberjack, rock salmon, or sailor's choice. These species are large, highly mobile, and predatory, in most subtropical and temperate boundary current ecosystems (Vergani et al., 2008; Miller et al., 2011). Along the western coast of North America, the yellowtail jack ( $S$. dorsalis) (formerly S. lalandi; see Martinez-Takeshita et al., 2015) ranges from Cabo San Lucas in Baja California Sur, Mexico, north to Point Conception, California (Baxter, 1960). Within U.S. territorial waters, yellowtail jack are most abundant in the U.S. portion of the Southern California Bight (SCB), a term used to denote the coastline stretching from Point Conception south to Cabo Colonet in Baja California, Mexico.
Total yearly recreational catch of yellowtail jack in California is often at least one order of magnitude greater than the entire commercial take for the same year (National Marine Fisheries Service, annual commercial landings statistics, release 3.0.4.0, available from website, accessed March 2019; Recreational Fisheries Information Network, total mortality by state, available from website, accessed March 2019). This discrepancy is evident in angler enthusiasm as well, as indicated by significant increases in the number of anglers venturing out to target yellowtail jack immediately after increased recreational catches are reported (Dotson and Charter, 2003). This increase in angling pressure also has residual effects on other, co-occurring species (Sutton and Ditton, 2005).

Although yellowtail jack captivate the angling public, aside from a small study sampling fewer than 50 individuals for stable isotope analysis (Madigan 
et al., 2018), there has been no research on their life history, movement patterns, or population structure along the California coast since the mid-1950s (Baxter, 1960). Improving our understanding of the biology of yellowtail jack along the western coasts of the United States and Mexico is a critical foundation for managing this taxon for fisheries value (both for sport and as food), ecosystem benefits, and potential in aquaculture (Sicuro and Luzzana, 2016).

Responding to the prominence of yellowtail jack in landings of nearshore fisheries in southern California and Baja California after World War II, the California Department of Fish and Game (now the Department of Fish and Wildlife) completed a detailed study on the biology and demography of yellowtail jack, as well as on their movements along the California and Mexico coastlines (Baxter, 1960). This work was a comprehensive description of the fish population during 1952-1957, with large sample sizes linked to the output of the prodigious fisheries yield at the time. However, the work lacked spatial resolution, for example, with no designation among fish caught in offshore versus inshore habitats. Furthermore, practically all fish were sampled or tagged along central Baja California, as opposed to within the SCB. Although central Baja California is the center of abundance for yellowtail jack and oceanographically similar to southern California (Jackson, 1986; Bograd and Lynn, 2003), the human population of southern California has been, and remains, higher than that of Baja California, with distinct anthropogenic pressures, including relatively higher recreational fishing pressure and nearshore eutrophication from urban and agricultural runoff (Schiff et al., 2000).

Yellowtail jack are believed to migrate seasonally into the SCB, moving northward as the water warms during the summer (rarely traveling north of Point Conception, except in highly anomalous warm years; Pearcy, 2002) and retreating south along the Baja California coastline during the winter and spring (Baxter, 1960). Along the route of their cross-border migrations, these fish encounter a diverse array of anthropogenic pressures, including the world's largest fleet of commercial passenger fishing vessels (CPFVs) operating in the SCB (Love, 2006).

The combination of increased human interactions and other anthropogenic effects with changed marine conditions within the SCB in the past 60 years necessitated a revisiting of the life history of yellowtail jack. Further, despite technical advances in fisheries research methods, Baxter's (1960) findings for age, growth, and diet are still used by fisheries managers in the United States today. Investigating the life history and biology of yellowtail jack with modern analytical techniques in the area in which they are most-heavily targeted will ensure that robust data exist with which to investigate potential changes in the biology of this species. Understanding how such changes might affect both the species and the fishery requires up-to-date life history data and is necessary for proactive management of this highly sought-after species. The results of the work presented here, which examined potential ontogenetic shifts in growth rate and diet, update our understanding of the biology of yellowtail jack in the SCB and establish a baseline for more targeted investigation into the biology and ecology of the yellowtail jack at the current northern extent of its range.

\section{Materials and methods}

\section{Study species}

This study focuses on the coastal population of yellowtail jack in the northeastern Pacific Ocean. This species was originally named $S$. dorsalis by Theodore Gill in 1863, then grouped together with $S$. lalandi in 1990 by Smith-Vaniz et al. (Smith-Vaniz, 1986; Smith-Vaniz et al., 1990). There is currently some disagreement as to the name of species of yellowtail jack in the eastern Pacific Ocean, with contradictory molecular findings from Premachandra et al. (2017) and Martinez-Takeshita et al. (2015). Although we acknowledge the controversy, we proceed here as per recommendations in Martinez-Takeshita et al. (2015) and use $S$. dorsalis as the scientific name for this species.

\section{Sample collection}

A total of 271 yellowtail jack, ranging in fork length (FL) from 22.7 to $162.7 \mathrm{~cm}$ (mean: $79.8 \mathrm{~cm}$; Suppl. Table), were collected aboard CPFVs and private fishing vessels by hook and line between July 2014 and September 2016, a period of time that encompassed an anomalous warmwater event and a strong El Niño-Southern Oscillation (ENSO) (NOAA Climate Prediction Center, Oceanic Niño Index cold and warm episodes by season, available from website, accessed January 2019). We conducted sampling at 10 locations within the SCB and along the Baja California coastline in an attempt to collect samples from as much of the range of the yellowtail jack as possible. We grouped those locations into 3 regions: inshore, offshore, and island (Fig. 1). It is important to note that yellowtail jack routinely move between these assigned regions.

Straight FL and opercular length (OL) were recorded and used to calculate an OL-to-FL scaling relationship (number of samples $[n]=151$ ). This relationship enabled estimation of FL for samples taken from heads or partial frames of yellowtail jack obtained after processing aboard CPFV or as donations by anglers. These samples were often easier to obtain and reduced the amount of fish sacrificed only for sampling purposes. In addition to measurements, sagital otoliths were extracted for age estimation, a plug of white muscle was taken from along the supraorbital crest of the head of the fish for stable isotope analysis, and the stomach was excised and immediately frozen for analysis of gut contents. Because of varying collection logistics, not all types of biological samples were successfully extracted from each fish.

\section{Age estimation}

Transverse sections of sagittal otoliths were used to estimate the age of yellowtail jack (Kimura et al., 1979; 


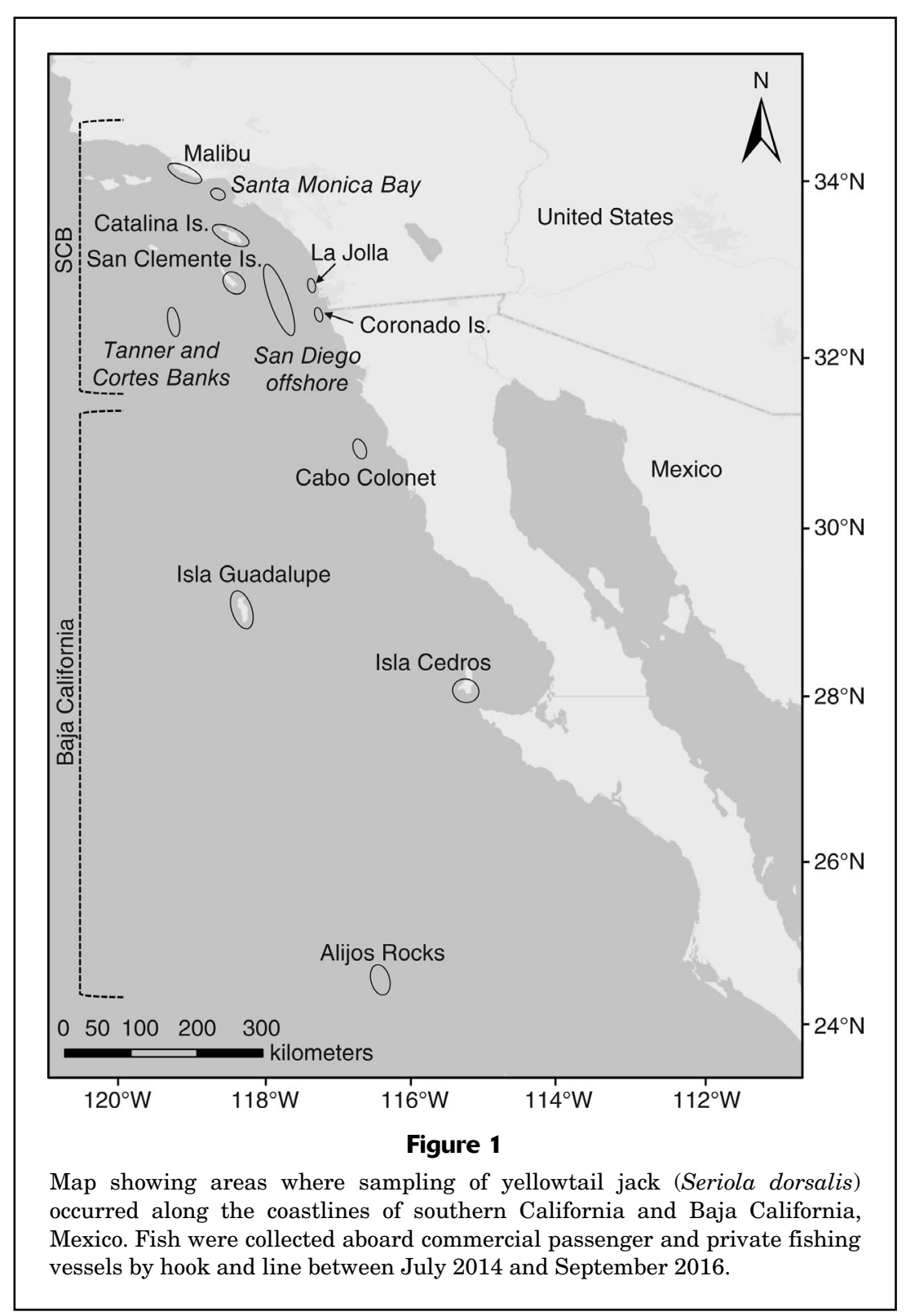

Redding, CA). The exposed section of the otolith was subsequently ground to the edge of the slide by using a decreasing series of wet polishing paper (400 grit [30-9 $\mu \mathrm{m}])$ affixed to a grinding wheel (model 900, South Bay Technology Inc., San Clemente, CA). The ground sagitta was then inverted, centered, ground, and polished until reaching the nucleus at approximately $500 \mu \mathrm{m}$ in thickness. The resulting transverse section was covered with a thin layer of Crystalbond to improve optical clarity (Zgliczynski, 2015). Polished otoliths (Suppl. Fig. 1) were examined by using a dissecting microscope outfitted with a digital camera and analyzed with digital imaging software (CaptaVision, vers. 5.1, ACCU-SCOPE Inc., Commack, NY).

After imaging, 3 separate readers examined each sample by using a singleblind method. Information concerning catch location and OL were kept from the readers during the age estimation process. Approximate ages were extrapolated by using the $1+$ method to number opaque rings beginning at the annulus for each specimen (Francis et al., 2014). When the reader counts for a specimen deviated by greater than 3 years, otoliths were reexamined and new estimates made. If between-reader agreement could not be reached after reexamination, the otolith in question was excluded from analysis. Additionally, an index of average percent error (APE) (Beamish and Fournier, 1981) and mean coefficient of variation (CV) (Chang, 1982) were calculated to estimate the relative precision of age estimates between readers.

Choat and Axe, 1996). For the samples of yellowtail jack that were examined, both sagittal otoliths were extracted through one vertical cut at the preoperculum. The sagittae were then rinsed in deionized water and air-dried. One sagitta was weighed and measured vertically (from rostrum to post-rostrum) and horizontally (left to right across nucleus). After the position of the otolith nucleus was determined, the sagitta was mounted on a microscope slide with the nucleus falling just below the edge, leaving the rostrum exposed at a $90^{\circ}$ angle. The sagitta was then secured by using a clear thermoplastic cement (821-3 Crystalbond 509 ${ }^{1}$, Ted Pella Inc.,

\footnotetext{
${ }^{1}$ Mention of trade names or commercial companies is for identification purposes only and does not imply endorsement by the National Marine Fisheries Service, NOAA.
}

\section{Size-at-age analysis}

Size-at-age data were fit by using the von Bertalanffy growth function (VBGF) (von Bertalanffy, 1938), defined as follows:

$$
L_{\mathrm{t}}=L_{\infty}\left(1-e^{-\mathrm{K}\left(\mathrm{t}-\mathrm{t}_{0}\right)}\right),
$$

where $L_{\mathrm{t}}=$ the length of a fish at age $t$;

$L_{\infty}=$ the asymptotic length or theoretical maximum length a species would reach if it lived indefinitely;

$K=$ the growth coefficient, which is a measure of the rate that maximum size is achieved;

$t=$ age in years; and

$t_{0}=$ the theoretical age for which length is 0 (Quinn and Deriso, 1999). 
Region-specific growth rates were generated for each sampling region and fit to size-at-age data by using the VBGF. The growth parameters $K$ and $L_{\infty}$ were also compared among regions by plotting $95 \%$ confidence ellipses around each parameter estimate (Kimura, 1980; Choat and Axe, 1996). Additionally, we calculated natural mortality (Pauly, 1980) for recently and historically sampled yellowtail jack, using VBGF parameters from Baxter (1960). Analyses were conducted by using the fishmethods (vers. 1.11-0; Nelson, 2018) and FSA (vers. 0.8.20; Ogle, 2018) packages in $\mathrm{R}$ (vers. 3.4.4; $\mathrm{R}$ Core Team, 2018).

\section{Diet analysis}

Full stomachs were dissected and weighed, with contents sorted by size through a series of graduated sieves $(1 \mathrm{~cm}$, $1 \mathrm{~mm}$, and $0.1 \mathrm{~mm}$ ); the empty, clean stomach was then reweighed. We sorted stomach contents from individual fish into functional groups (demersal and pelagic fish, squid, demersal crustaceans, benthic invertebrates, and amorphous material), identifying contents to species when possible (Table 1). Whole fish and invertebrates were enumerated, weighed, and identified to species. Otoliths were identified primarily by using images from Lowry (2011), vertebrae were identified by using images from Clothier (1950), and cephalopod beaks were identified by using reference samples at the NOAA Southwest Fisheries Science Center. Paired structures (otoliths, beaks, and crustacean eyes) were counted and divided by 2 , to estimate the number of individual prey items. Amorphous, unidentifiable contents were quantified by subtracting the total prey weight from the difference between the full and empty stomach weights. Mean percentages were calculated for 4 major stomach content groups-fish, crustaceans, cephalopods, and amorphous material-for comparison of proportional representation across sampling location, sampling region, and body size of yellowtail jack.

Many of the yellowtail jack analyzed were collected aboard CPFV, which have fishing operations that predominantly use live bait and chum in the form of sardines or anchovies to attract gamefish to the boat. In an effort to control for the amount of CPFV chum in stomachs of yellowtail jack, we noted the number of species among the fresh, undigested chum for each sample processed. Additionally, even without active chumming, most CPFV catches come in concentrated events when the vessel

\section{Table 1}

Results from analysis of the contents of 173 stomachs from yellowtail jack (Seriola dorsalis) collected within the Southern California Bight (SCB) and in Baja California, Mexico, between July 2014 and September 2016. An " $x$ " indicates that a species or taxon was found in the stomach of a fish collected in a sampling region or size group; an en dash (-) indicates that no data are available because no individual of the taxon was sampled in the region or size group. Lengths used for size groups are fork lengths calculated with an opercular-length-to-fork-length scaling relationship. $n=$ number of samples.

\begin{tabular}{|c|c|c|c|c|c|c|c|c|c|}
\hline \multirow[b]{2}{*}{ Functional group } & \multirow[b]{2}{*}{ Species } & \multicolumn{5}{|c|}{ Sampling region } & \multicolumn{3}{|c|}{ Size group } \\
\hline & & Inshore & Offshore & Island & SCB & Baja & $\begin{array}{c}\text { Small } \\
0-60 \mathrm{~cm} \\
(n=19)\end{array}$ & $\begin{array}{c}\text { Medium } \\
60-90 \mathrm{~cm} \\
(n=90)\end{array}$ & $\begin{array}{c}\text { Large } \\
90-150 \mathrm{~cm} \\
(n=37)\end{array}$ \\
\hline \multirow[t]{13}{*}{ Fish } & Engraulis mordax & $x$ & $x$ & $x$ & $x$ & $x$ & $x$ & $x$ & $x$ \\
\hline & Sardinops sagax & $x$ & $x$ & $x$ & $x$ & $x$ & $x$ & $x$ & $x$ \\
\hline & Trachurus symmetricus & $x$ & $x$ & $x$ & $x$ & $x$ & - & $x$ & $x$ \\
\hline & Scomber japonicus & $x$ & $x$ & $x$ & $x$ & $x$ & $x$ & $x$ & $x$ \\
\hline & Sebastes spp. & $x$ & $x$ & $x$ & $x$ & $x$ & - & $x$ & $x$ \\
\hline & Embiotocidae & $x$ & $x$ & $x$ & $x$ & $x$ & - & $x$ & $x$ \\
\hline & Cololabis saira & - & $x$ & - & - & $x$ & - & $x$ & $x$ \\
\hline & Halichoeres semicinctus & - & - & $x$ & $x$ & $x$ & - & $x$ & $x$ \\
\hline & Citharichthys sordidus & $x$ & - & $x$ & - & - & - & - & $x$ \\
\hline & Syngnathus spp. & $x$ & - & $x$ & - & - & - & - & $x$ \\
\hline & Synodus lucioceps & $x$ & - & - & $x$ & - & - & $x$ & $x$ \\
\hline & Chromis punctipinnis & - & $x$ & - & $x$ & - & - & $x$ & - \\
\hline & Unidentified fish & $x$ & $x$ & $x$ & $x$ & $x$ & $x$ & $x$ & $x$ \\
\hline Pelagic red crab & Pleuroncodes planipes & $x$ & $x$ & $x$ & $x$ & $x$ & $x$ & $x$ & $x$ \\
\hline Krill & Euphausiacea & - & $x$ & $x$ & $x$ & $x$ & - & $x$ & $x$ \\
\hline Rock shrimps & Sicyonia spp. & $x$ & - & $x$ & $x$ & - & - & $x$ & $x$ \\
\hline $\begin{array}{l}\text { California market } \\
\text { squid }\end{array}$ & $\begin{array}{l}\text { Doryteuthis (Amerigo) } \\
\text { opalescens }\end{array}$ & $x$ & $x$ & $x$ & $x$ & - & - & $x$ & $x$ \\
\hline \multirow[t]{2}{*}{$\begin{array}{l}\text { Misc. } \\
\text { invertebrates }\end{array}$} & Isopod & $x$ & - & - & - & - & - & $x$ & - \\
\hline & Urchin & $x$ & - & - & - & - & - & - & $x$ \\
\hline \multicolumn{2}{|c|}{ Total number of unique species } & 14 & 11 & 13 & 13 & 10 & 4 & 15 & 16 \\
\hline
\end{tabular}


encounters schooling, actively feeding fish. These fish are often all feeding on the same prey items. To control for the over-representation of prey items from discrete feeding events, we limited sampling to no more than 10 fish from any one CPFV trip.

To account for the multinomial (non-independent) nature of percentage data on stomach contents, we used a resampling approach to formally test the null hypothesis that the proportional diets of varying size classes of yellowtail jack do not differ. Because the diet composition of an individual fish is the result of numerous discrete choices made during foraging activities, each item consumed can be assigned to a diet category on the basis of taxonomy (or functional group) and the number of diet categories is determined by the level of dietary resolution. The total percentage of each diet category is bound between $0 \%$ and $100 \%$ and is dependent on the values of the other diet categories observed. As such, stomach content data violates several assumptions of normality and independence required for many traditional statistical approaches.

We used a tailored resampling routine following an analytical approach introduced in Barott et al. (2012) to address the multinomial nature of diet data. In this approach, mean relative diet composition for individuals from one size class is calculated as the size-class-specific centroid of the data in $n$-dimensional space (where $n$ is the number of diet categories), and the mean for all individuals from across all size classes is calculated as the global centroid from all samples. For our study, the mean intercentroid distance among size classes was calculated by measuring the Euclidean distances between the centroids for each population (or size class) from the global centroid. Through resampling (10,000 iterations), we generated a null distribution of mean intercentroid distances by repeatedly scrambling size-class affiliations of diet composition data from all individuals and calculating the intercentroid distance. We then compared the actual mean intercentroid distance to this null distribution to test whether mean diets differed among size classes of yellowtail jack. If the null hypothesis (of no difference in diet composition among size classes) was rejected, the method above was repeated individually for all pairs of size classes to generate pairwise comparisons among each combination. The null hypothesis for the post-hoc test was rejected if $P<0.01$. Using Euclidean distances is, in most cases, robust across levels of aggregation of diet categories given that the approach does not de facto create higher sensitivity to an increased number of functional groups (Zgliczynski et al., 2019).

\section{Bulk carbon and nitrogen isotopes}

We analyzed samples of white muscle collected from along the supraorbital crest for both carbon $\left(\delta^{13} \mathrm{C}\right)$ and nitrogen $\left(\delta^{15} \mathrm{~N}\right)$ isotopes to further investigate regional or size-specific trophic differences in yellowtail jack from the SCB. Although the isotopic turnover rate in white muscle of this species is currently unknown, it is assumed to be approximately 1 year $\left(\right.$ Madigan $\left.^{2}\right)$. As such, their isotopic signature should reflect their aggregate diet over that time period (Peterson and Fry, 1987). Tissue samples were freeze-dried with a 2.5-L FreeZone benchtop freeze dryer (Labconco Corp., Kansas City, MO) for $48 \mathrm{~h}$ to remove all moisture. Samples were then pulverized by using a mechanical grinding mill (Wig-L-Bug, Dentsply Sirona, Charlotte, NC), and a 1-mg subsample (encapsulated in foil) was analyzed for $\delta^{13} \mathrm{C}$ and $\delta^{15} \mathrm{~N}$. Analysis was performed on a Costech Elemental Combustion System ECS 4010 nitrogen and protein analyzer (Costech Analytical Technologies Inc., Valencia, CA) interfaced with a Finnigan DELTAplus XP stable isotope mass spectrometer (Thermo Fisher Scientific Inc., Waltham, MA) at Scripps Institution of Oceanography, University of California, San Diego. Isotopic values are expressed in $\delta^{13} \mathrm{C}$ or $\delta^{15} \mathrm{~N}$, where $\delta=1000 \times\left[\left(R_{\text {sample }} / R_{\text {standard }}\right)^{-1}\right]$ and $R_{\text {sample }}$ and $R_{\text {standard }}$ are ratios of the heavy to light isotope in parts per thousand. The standards used were Vienna-Pee Dee Belemnite and atmospheric $\mathrm{N}_{2}$. The within-run run standard deviation of a glutamic standard was $<0.2 \%$ for both $\delta^{13} \mathrm{C}$ and $\delta^{15} \mathrm{~N}$.

\section{Results}

\section{Opercular length-fork length relationship}

Opercular lengths of yellowtail jack scale isometrically with FLs $\left(F L=4.3864(O L)^{0.9854}\right.$, coefficient of determination $\left[r^{2}\right]=0.951$ ), with a strong, linear relationship between the 2 measurements. The relationship of OL to FL was plotted for 151 fish from all sampling locations (Suppl. Fig. 2). Fork lengths ranged between 28.0 and $156.0 \mathrm{~cm}$ (mean: $79.8 \mathrm{~cm}$ ), and OLs ranged from 7.1 to $38.3 \mathrm{~cm}$ (mean: $19.0 \mathrm{~cm}$ ). This relationship was used to estimate FL for the remaining samples collected from angler discards or partial remains of yellowtail jack. Because it is simpler to visualize overall fish size instead of OL, all subsequent length information from our study is reported in units of FL estimated with an OL-to-FL scaling relationship.

\section{Age estimation}

We estimated ages for 235 yellowtail jack from across the SCB and from 3 locations along the Baja California coast. Fish ranged from 22.7 to $162.7 \mathrm{~cm}$ in FL calculated with an OL-to-FL scaling relationship (Table 2). Fish had OL of $5.4-38.3 \mathrm{~cm}$ and ages of $1-22$ years (Table 2). The APE and CV were $8.75 \%$ and $11.69 \%$, respectively. Although there were no spatial differences in size at age and growth rate estimates at ages younger than 8 , island fish reached larger sizes ( $>110 \mathrm{~cm} \mathrm{FL)} \mathrm{and} \mathrm{greater} \mathrm{ages}$ ( $>13$ years) than both inshore and offshore fish. Additionally, fish collected in Baja California were generally larger and older than fish collected within the SCB (mean size and age: $92.4 \mathrm{~cm} \mathrm{FL}$ and 9.04 years versus

\footnotetext{
${ }^{2}$ Madigan, D. 2016. Personal commun. Univ. Windsor, 401 Sunset Ave., Windsor, ON N9B 3P4, Canada.
} 


\section{Table 2}

Size ranges by year class for 235 yellowtail jack (Seriola dorsalis) collected within the Southern California Bight and in Baja California, Mexico, during 2013-2016. Also provided are Baxter's (1960) size at age for each corresponding year class, measured and calculated by using the von Bertalanffy growth function (VBGF). In this study, it was not possible to measure the straight fork length (FL) for all sampled fish; therefore, the lengths in this table are estimates from the use of an opercular-length-to-FL scaling relationship. Mean FL and standard error of the mean (SE) are included. $n=$ number of samples. An en dash (-) indicates insufficient data.

\begin{tabular}{|c|c|c|c|c|c|c|c|c|}
\hline \multirow{2}{*}{$\begin{array}{l}\text { Year } \\
\text { class }\end{array}$} & \multirow[b]{2}{*}{$n$} & \multicolumn{2}{|c|}{ Size range $(\mathrm{cm})$} & \multirow{2}{*}{$\begin{array}{c}\text { Mean } \\
\text { FL }(\mathrm{cm})\end{array}$} & \multirow[b]{2}{*}{$\mathrm{SE}$} & \multicolumn{3}{|c|}{ FL $(\mathrm{cm})$ from Baxter $(1960)$} \\
\hline & & Min. FL & Max. FL & & & $n$ & Mean FL & VBGF FL \\
\hline 1 & 3 & 22.7 & 37.9 & 30.13 & 4.39 & 234 & 50.6 & 48.83 \\
\hline 2 & 15 & 37.9 & 57.0 & 46.03 & 1.60 & 122 & 63.4 & 59.01 \\
\hline 3 & 24 & 40.4 & 65.9 & 56.68 & 1.33 & 183 & 70.6 & 67.92 \\
\hline 4 & 34 & 45.9 & 77.0 & 64.59 & 1.21 & 115 & 78.3 & 75.68 \\
\hline 5 & 25 & 62.1 & 88.9 & 74.88 & 1.60 & 61 & 83.1 & 82.47 \\
\hline 6 & 25 & 68.9 & 88.4 & 80.25 & 1.17 & 18 & 87.2 & 88.39 \\
\hline 7 & 26 & 67.2 & 94.4 & 85.15 & 1.36 & 11 & 89.3 & 93.56 \\
\hline 8 & 23 & 73.5 & 104.2 & 91.94 & 1.40 & 14 & 95.8 & 98.07 \\
\hline 9 & 13 & 79.1 & 100.8 & 92.93 & 1.58 & 5 & 100.8 & 102.02 \\
\hline 10 & 12 & 88.9 & 104.6 & 96.97 & 1.67 & 6 & 103.5 & 105.46 \\
\hline 11 & 15 & 84.6 & 107.2 & 99.25 & 1.61 & 9 & 108.2 & 108.47 \\
\hline 12 & 3 & 90.6 & 111.0 & 101.37 & 5.92 & 7 & 112.7 & 111.09 \\
\hline 13 & 5 & 105.1 & 120.4 & 112.74 & 2.75 & - & - & 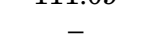 \\
\hline 14 & 2 & 117.4 & 122.1 & 119.75 & 2.35 & - & - & - \\
\hline 15 & 1 & 113.6 & 113.6 & 113.60 & - & - & - & - \\
\hline 16 & 3 & 115.3 & 122.5 & 118.13 & 2.22 & - & - & - \\
\hline 17 & 2 & 109.3 & 120.8 & 115.05 & 5.75 & - & - & - \\
\hline 19 & 1 & 144.3 & 144.3 & 144.30 & - & - & - & - \\
\hline 21 & 1 & 151.6 & 151.6 & 151.60 & - & - & - & - \\
\hline 22 & 1 & 162.7 & 162.7 & 162.70 & - & - & - & - \\
\hline
\end{tabular}

$74.5 \mathrm{~cm} \mathrm{FL}$ and 5.75 years, $P<0.005)$. Natural mortality was 0.346; using Baxter's (1960) findings, we calculated a historical natural mortality of 0.261 .

We observed potential differences between mean sizes of male (81.2 cm FL) and female (88.4 cm FL) fish; however, our sample sizes of sexed fish (female: $n=66$; male: $n=44$ ) were too low for conclusive results $(P=0.087)$. Because we predominantly sampled angler discards, fish often were already filleted or the gonads were otherwise compromised prior to sample collection.

\section{Stomach content analysis}

Yellowtail jack within the SCB are non-discriminate mesopredators that consume a mix of pelagic and demersal fish species as well as crustaceans and the California market squid, Doryteuthis (Amerigo) opalescens. Of the 173 stomachs analyzed, 25.4\% (44 stomachs) were empty, and the remaining $74.6 \%$ were at least partially full, with over half the contents composed of amorphous or mostly digested material (mean proportion by weight: $65.4 \%$ ). Out of the remaining contents, we successfully identified 19 species. Fish species, particularly small pelagic species, including the Pacific sardine (Sardinops sagax), northern anchovy (Engraulis mordax), Pacific chub mackerel (Scomber japonicus), and jack mackerel (Trachurus symmetricus), accounted for $61.5 \%$ of all identified contents. The pelagic red crab (Pleuroncodes planipes) was the single most abundant species, present in $22.7 \%$ of all examined stomachs. Larger fish consumed a wider diversity of prey species, and the proportional representation of prey functional groups differed significantly between size classes $(P<0.01)$ (Fig. 2).

\section{Stable isotope analysis}

We quantified $\delta^{13} \mathrm{C}$ and $\delta^{15} \mathrm{~N}$ levels for 225 yellowtail jack collected throughout the SCB and coastal waters of Baja California. Values of neither $\delta^{13} \mathrm{C}$ nor $\delta^{15} \mathrm{~N}$ varied between sampling regions or locations, but they did increase with increasing body size $\left(r^{2}=0.422, P<0.005\right)$ (Fig. 3A). Levels of $\delta^{15} \mathrm{~N}$ increased significantly $\left(r^{2}=0.596, P<0.01\right)$ with increasing body size, and there was no difference in the rate of increase between fish caught inshore or offshore. Values of $\delta^{13} \mathrm{C}$ varied spatially, with $\delta^{13} \mathrm{C}$ levels remaining relatively constant in fish caught offshore and increasing significantly with FL for fish collected inshore $(P<0.005)$ (Fig. 3B). 


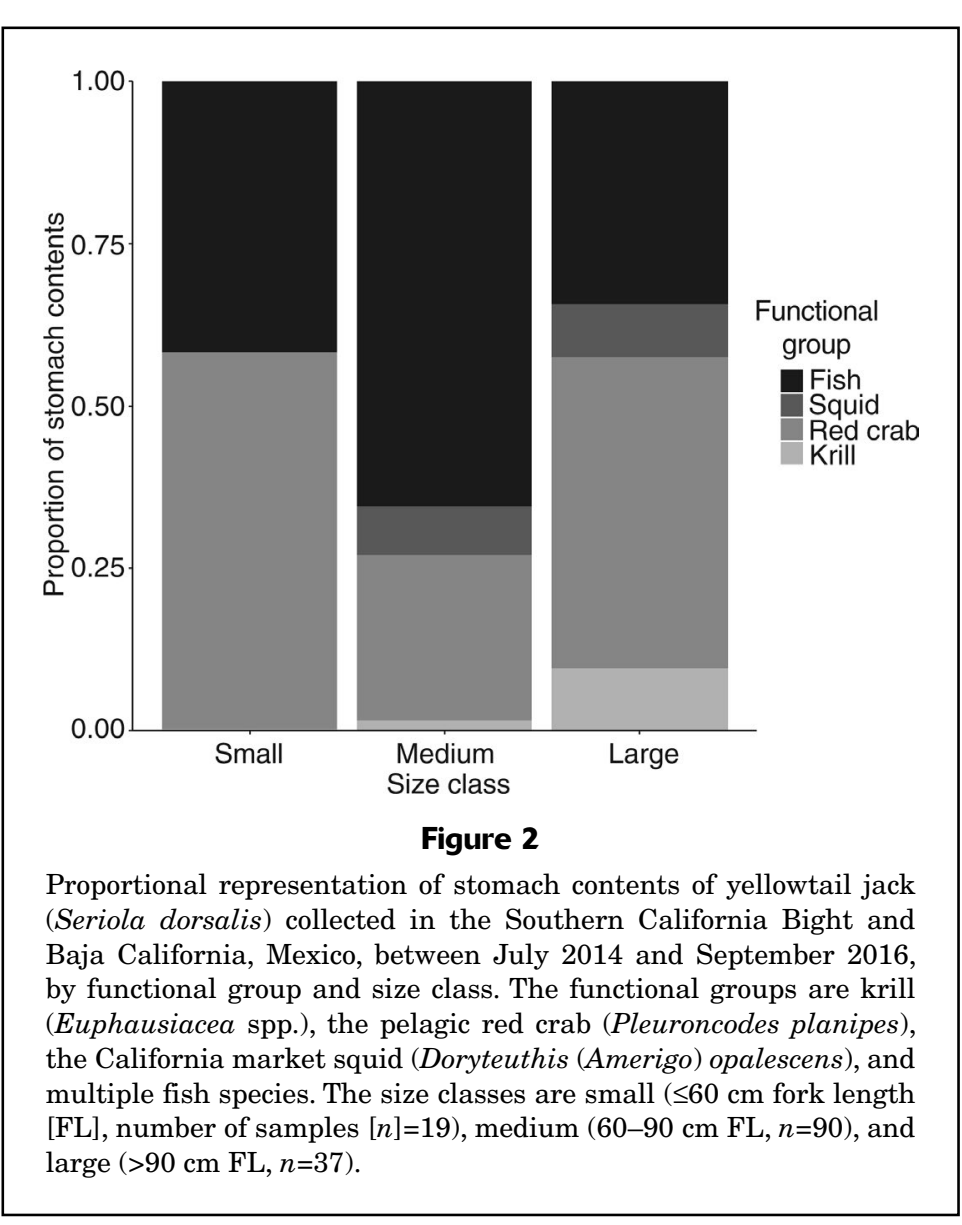

information for each sample, as well as to better understand effects of recreational fishing on size classes of yellowtail jack.

\section{Opercular length-fork length relationship}

Several conversion factors for using FL to estimate total length already exist for populations of 2 species formerly considered to be a single species: yellowtail jack along the Pacific coast of North America, S. dorsalis, and yellowtail jack in Australia and New Zealand, S. lalandi (Baxter, 1960; Holdsworth et al., 2013; McKenzie et al., 2014). The creation of a robust conversion factor for expressing OL in FL means that accurate estimates of FL can be extrapolated from discarded heads of yellowtail jack. Because many anglers, fishing vessel crew members, and fish processors are happy to donate heads of yellowtail jack to researchers (senior author, personal observ.), using OL to estimate body length is an effective method of maximizing sample size and sampling efficiency given that heads also can provide otoliths for aging and white muscle, from along the supraorbital crest, for stable isotope analysis.

\section{Age and growth estimation}

This work is the first to estimate ages by using otoliths from yellowtail jack collected within the SCB. The single previous examination of yellowtail jack (Baxter, 1960) collected fish along coastal

\section{Discussion}

Our results indicate that the SCB is home to one contiguous, seasonally abundant population of yellowtail jack. Patterns observed in diet, trophic position, and growth rate are driven primarily by temporal and ontogenetic influences, and spatial variation between different regions of the SCB is less significant than originally assumed. Although these findings run contrary to anecdotal reports of geographic differences within populations of yellowtail jack in the SCB, they are supported by tagging data (senior author, unpubl. data) as well as genetic analysis (Martinez-Takeshita et al., 2015).

For this study, we examined multiple life history characteristics in order to update our current understanding of the biology of yellowtail jack within the SCB. Despite the popularity of this species as a sport and food fish, the paucity of current biological data as well as the lack of a formal stock assessment means that gauging population health or effects of current management strategies is difficult. Our goal was to update the previous demographic analysis (Baxter, 1960) with data collected from within the SCB and analyzed with modern techniques and to facilitate future research and management with a new, SCB-focused data set. We exclusively sampled fish that were caught recreationally to obtain detailed spatial central Baja California, several hundred kilometers to the south of the SCB, and used scales to estimate ages. Sampled fish in our study were 1-22 years old and 22-156 cm FL, and the largest and oldest individuals were approximately equal in length and age to the largest fish of another species of yellowtail jack, $S$. lalandi, collected in New Zealand and Australia (Stewart et al., 2004; McKenzie et al., 2014). The similarity in size and age was surprising considering anecdotal accounts of yellowtail jack being consistently larger in waters of New Zealand than in the northeast Pacific Ocean.

We saw no differences in calculated growth rates and habitats within the SCB. However, yellowtail jack collected from central Baja California were significantly larger and older than fish sampled from the SCB (mean size: $92.4 \mathrm{~cm}$ FL versus $74.5 \mathrm{~cm} \mathrm{FL,} P<0.005$ ) (Fig. 4). The differences in calculated size at age as well as in $L_{\infty}$ between fish from Baja California and those from SCB were driven by the largest (>115 cm FL) fish, which were all collected from Islas Cedros and Guadalupe in Baja California. Both islands are known by anglers as prime locations to catch large yellowtail jack, with anglers at Isla Guadalupe routinely catching fish over $25 \mathrm{~kg}$ (Ben-Aderet, 2017). Fish over $20 \mathrm{~kg}$ are extremely rare within the SCB (Bellquist and Semmens, 2016), but maximum lengths between inshore, offshore, and island 


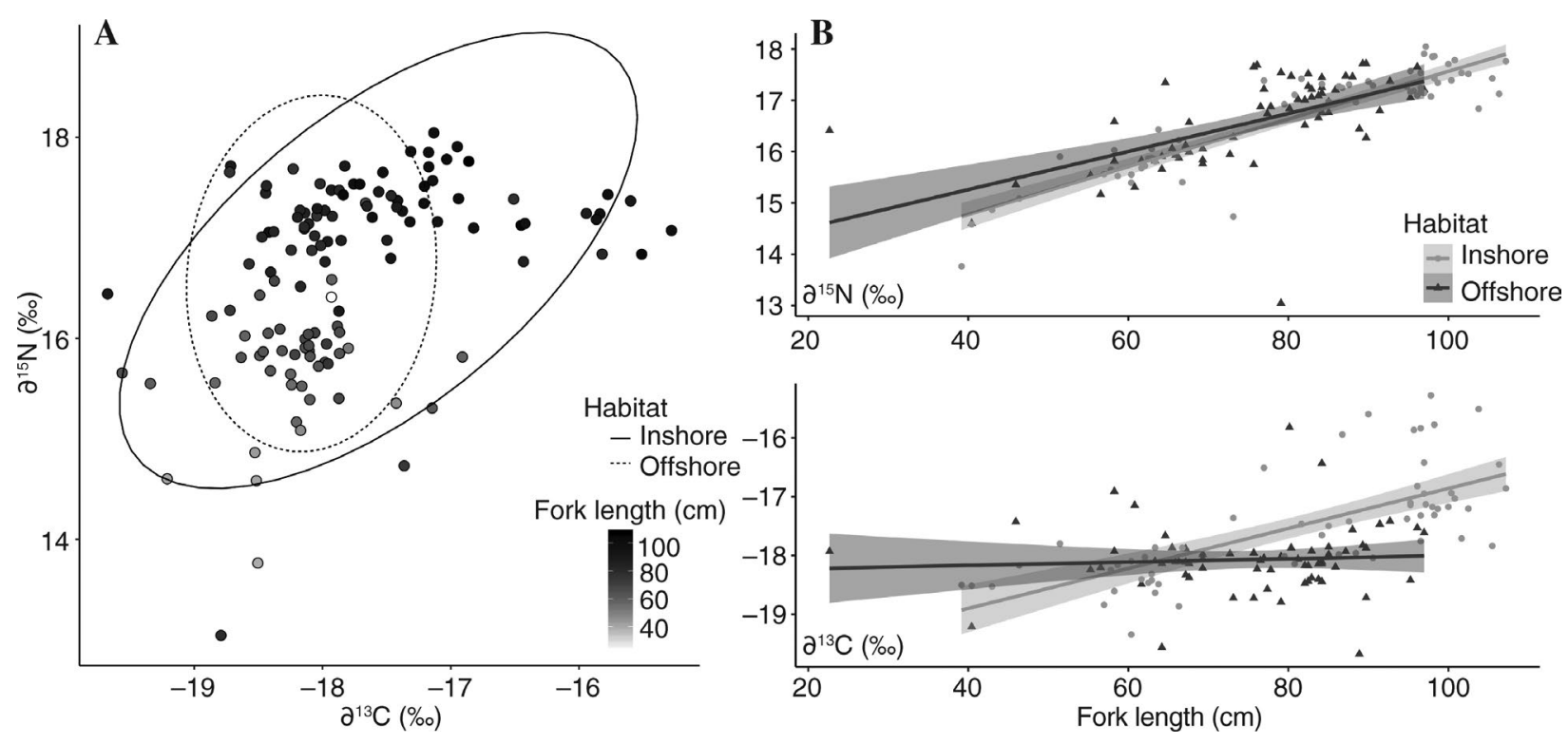

Figure 3

(A) Relationship of carbon $\left(\delta^{13} \mathrm{C}\right)$ to nitrogen $\left(\delta^{15} \mathrm{~N}\right)$ stable isotope levels, given in parts per thousand (\%o), for yellowtail jack (Seriola dorsalis) collected in inshore and offshore habitats in the Southern California Bight and in Baja California, Mexico, between July 2014 and September 2016. Darker shading of points indicates larger fish size, and ellipses represent 95\% confidence intervals. Offshore $\delta^{13} \mathrm{C}$ and $\delta^{15} \mathrm{~N}$ values are almost completely within those of inshore sampled fish. (B) Relationships of $\delta^{15} \mathrm{~N}$ (top panel) and $\delta^{13} \mathrm{C}$ (bottom panel) levels to fork length (FL) and sampling habitat. The shaded areas represent $95 \%$ confidence intervals. The point where the lines for inshore and offshore fish intersect corresponds with the size at which yellowtail jack are thought to transition from offshore to inshore habitats.

results of genetic analysis (albeit with low sample sizes: 4 in the SCB and 10 in central Baja California) reaffirm the theory of a single contiguous population in the SCB and Baja California (Martinez-Takeshita et al., 2015). However, it is currently unknown if yellowtail jack in waters off Isla Guadalupe leave the island and venture north into the SCB or are year-round residents and, therefore, isolated from the general population in the SCB.

\section{Sizes of fish in Baja California: evidence of a possible refuge}

Working under the notion of one contiguous population, we assume that the truncated $L_{\infty}$ of yellowtail jack from the SCB was primarily due to elevated fishing pressure and mortality in the SCB, although generally cooler ocean temperatures in the SCB versus Baja California and differences in forage assemblage might play a role (Stewart, 2011; Abbink et al., 2012). The relative lack of pressure at Isla Guadalupe is likely a result of isolation and distance from both mainland population centers and the nearest fishing port. Because most of the total take of yellowtail jack in the SCB is recreational rather than commercial, remote and isolated areas are more likely to serve as de facto refuges from fishing pressure (StuartSmith et al., 2008).

The hypothesis that remote regions of the SCB and Baja California coast serve as virtual refuges carries with it potential for unexpected climate-mediated effects (Perry et al., 2005). Because the SCB is the northern extent of the range of this species, northward range expansion could lead to increased fishing mortality due to yellowtail jack overwintering in the SCB (and, therefore, spending more time closer to elevated recreational fishing pressure). Such range effects are a real possibility because southern California's marine environment is warming and, in turn, would mean more yellowtail jack year-round in the SCB and associated increases in fishing pressure and mortality (Gillanders et al., 2001; Hobday and Evans, 2013; Champion et al., 2018).

\section{Comparisons of size-at-age estimates}

To update our understanding of the biology of yellowtail jack in the SCB and to compare our estimates of size at age with previous work, we estimated ages by using transversesectioned sagittal otoliths. Previously, Baxter (1960) estimated ages of yellowtail jack with annual growth rings on scales. His length-at-age estimations are the sole such work on yellowtail jack and are still used by fisheries managers. In the SCB, fish heads are readily available as angler discards; therefore, obtaining sagittal otoliths to estimate ages, although time-consuming, is relatively simple. When possible, we collected scales as well, but we were unable to replicate Baxter's (1960) methods and to obtain reliable age 


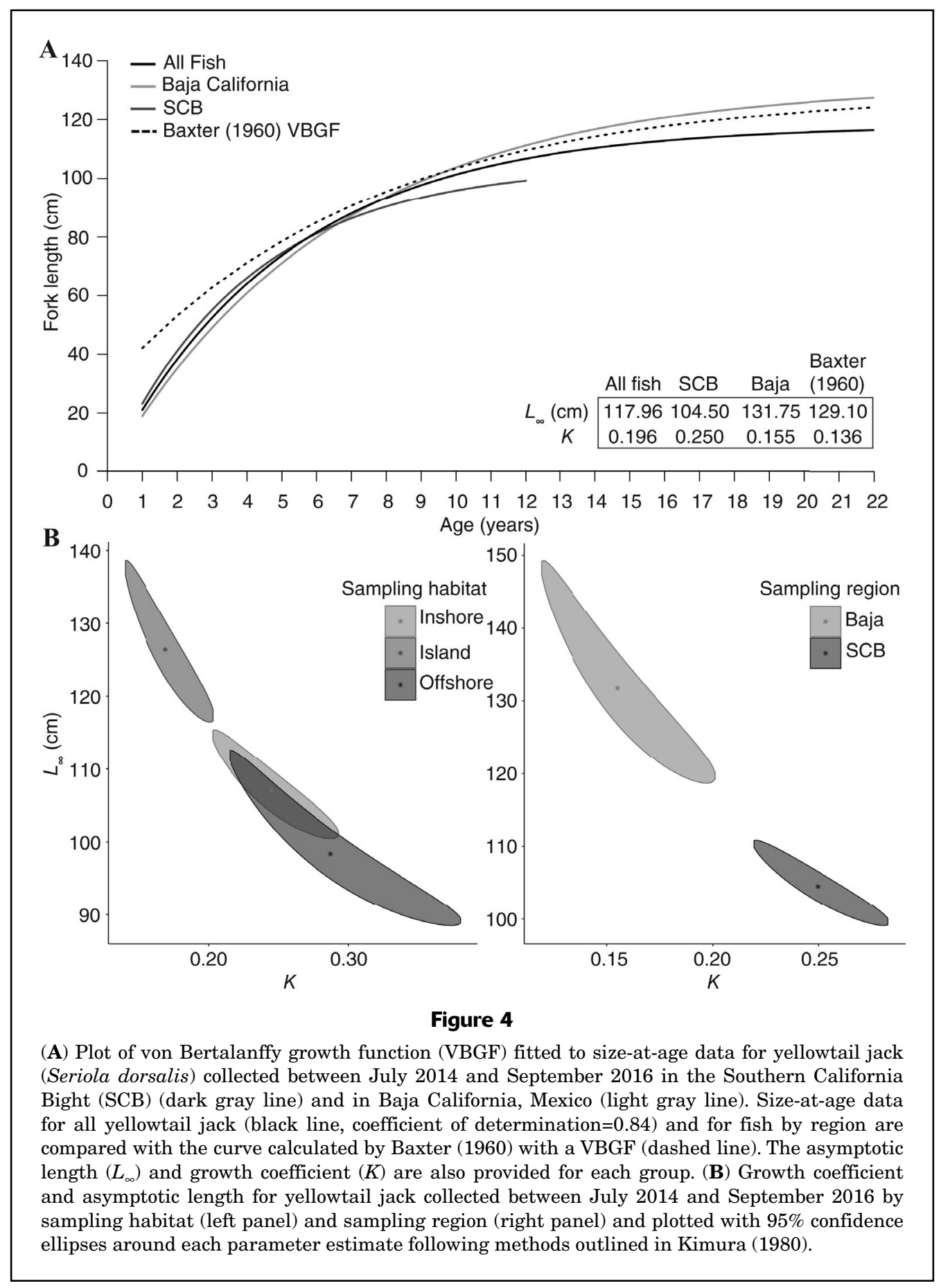

estimations. However, Gillanders et al. (1999) compared age estimation methods by using otoliths, vertebrae, and scales from yellowtail jack collected in Australia, concluding that, aside from estimates for fish displaying only one growth zone, estimates of mean size at age from analysis of scales were similar to those from aging with otoliths (Gillanders et al., 1999). The primary issue with using scales to estimate age is a lack of definition in early years, primarily year 1 (Gillanders et al., 1999; Shiraishi et al., 2010).
Despite this issue, Baxter's (1960) calculated values for VBGF parameters $L_{\infty}$ and $K$ are very close to our values for fish collected in central Baja California outside of the SCB. This comparability serves to further validate the results of Baxter (1960) because all samples were collected from central Baja California.

Interestingly, when reviewing age estimations and VBGF calculations from Baxter (1960), we noticed a 0.59 -year ( 7-month) offset in his estimation of $t_{0}$. When 
plotted with the offset, Baxter's (1960) measured mean size at age for each year better approximates his calculated values (Fig. 4). It is unclear as to why this offset exists because no mention of it is made in that publication, despite the size being calculable from data plots. This offset could potentially be a correction for age estimates based on scales because Baxter (1960) claims that annuli on scales of yellowtail jack do not form until the second winter following hatching (when fish are 18 months old). The findings of Gillanders et al. (1999) support this claim as well, as they were unable to find 1-year-old fish when they used scales. Another potential explanation of the 7-month offset could be that he wanted to backdate fish ages to 1 January, given that spawning along the coasts of California and Mexico is thought to peak in mid-summer (with 1 July being 7 months after 1 January) (Baxter, 1960; Sumida et al., 1985). Unfortunately, these 2 potential explanations are simply conjecture. We were unable to obtain any of Baxter's (1960) original raw data or notes to explore hypotheses.

\section{Early growth: issues for accurate age estimation}

Yellowtail jack in the SCB have a similar overall population age structure to that of those from Australia, New Zealand, and Baja California (Baxter, 1960; Gillanders et al., 1999; Mckenzie et al., 2014). However, differences in length at age for young fish (ages 0-3) still need to be resolved. Baxter (1960) reports a mean FL of $50.6 \mathrm{~cm}$ (range: $37.1-63.3 \mathrm{~cm}$ ) for age-1 fish and a mean FL of $63.4 \mathrm{~cm}$ for age-2 fish (range: $52.0-70.9 \mathrm{~cm}$ ). These mean sizes are much larger than those for our age-1 and age-2 fish (mean size: 26.3 and $44.1 \mathrm{~cm} \mathrm{FL}$, respectively). This discrepancy could be partly due to our smaller sample size for fish $<65 \mathrm{~cm} \mathrm{FL}$ or to the different structures used for age estimation. Gillanders et al. (1999) found that estimates of age at scale-derived lengths are generally lower than age estimates from either otoliths or vertebrae and that scale and otolith readings diverged below age 4 (Gillanders et al., 1999).

However, the difference in sizes of year 1 and 2 fish could simply be due to differences in counting the first growth zone on whatever structure was used for age estimation. Our length estimates for yellowtail jack from the SCB were similar to estimates for those from New Zealand when aged in accordance to the 1+ hypothesis (Francis et al., 2014). If 1 year is added to Baxter's length calculations, they closely mirror our findings, especially the estimates for young fish (<4 years) (Fig. 4). The 1+ hypothesis states that the first growth zone is formed during autumn-winter of the fish's second year, an approximate age of 18 months. Because of this lag in formation of the first growth zone, Francis et al. (2014) recommended that readers of otoliths from yellowtail jack add 1 year to their age counts.

Gillanders et al. (1999) was unable to classify any scaleaged fish as year class 1 , a very different finding than that of Baxter (1960). This issue of difficulty in classifying early year classes (1 and 2) in species of Seriola has been reported at least twice in the literature, both for greater amberjack (S. dumerili) from the Gulf of Mexico (Manooch and Potts, 1997) and for yellowtail jack from New Zealand (McKenzie et al., 2014). In both instances, the authors recommended further work to validate the position of the first annual growth zone on otoliths from fish of Seriola species.

Because of the difficulty of sampling wild yellowtail jack under $\sim 20 \mathrm{~cm} \mathrm{FL,} \mathrm{our} \mathrm{study} \mathrm{made} \mathrm{no} \mathrm{attempt} \mathrm{to}$ determine the annual otolith deposition zones. Gillanders et al. (1999) analyzed marginal increments on whole otoliths of fish aged as 2-4 years old and suggested that 1 zone is laid down per year in the Southern Hemisphere during winter (August-September). Stewart et al. (2004) believed that identification of the first annual zone is still problematic; our findings support this notion as well. Most recently, Francis et al. (2014) attempted to determine the location of the first growth zone in yellowtail jack from New Zealand. Although they failed to determine its location with any certainty, their results indicate that adding 1 year to the counted ages is the best current method and is how we estimated ages for this study. Further research validating the formation and position of the first growth zone should improve future age estimations for yellowtail jack in the SCB.

\section{Elevated sea-surface temperatures: evidence of possible effects on populations}

Climate-mediated recruitment pulses are possibly reflected in age-length frequency within the 235 fish sampled for this study. In the SCB, warmer-than-average conditions are coincident with El Niño summers (positive anomaly $>0.5^{\circ} \mathrm{C}$ in the ENSO 3.4 region) (Chavez et al., 2002) and are thought to support spawning of yellowtail jack in the outer-SCB as well as to correlate with increased success in recruitment of yellowtail jack (Tian et al., 2012). Mean and median ages for all yellowtail jack were 6.0 and 6.2 years, respectively. These ages correspond with spawning during summer 2009. The climate of 2009 was a mild El Niño (positive anomaly of $0.9^{\circ} \mathrm{C}$ in the ENSO 3.4 region), with elevated ocean temperatures in the SCB $\left(\mathrm{SIO}^{3}\right)$. Additionally, fish in the 90th percentile of our size distribution were larger than $96 \mathrm{~cm} \mathrm{FL} \mathrm{and,} \mathrm{according}$ to our age estimations, greater than 10 years old. These fish most likely spawned between 2003 and 2006, again, a period of elevated sea-surface temperatures during summer in the SCB. The prevalence of fish resulting from spawning during anomalously warm-water conditions in the SCB, coupled with cyclical increases and decreases in yearly catch, further supports the idea that both spawning and recruitment are greater in the SCB during episodes of elevated sea-surface temperatures.

\footnotetext{
${ }^{3}$ SIO (Scripps Institution of Oceanography). 2019. Surface temperatures collected at Scripps Pier in La Jolla, CA, by Birch Aquarium at Scripps staff and volunteers. Data provided by the Shore Stations Program sponsored at SIO by the Division of Boating and Waterways, California State Parks. [Available from website, accessed February 2019.]
} 


\section{Size-mediated opportunistic predators}

Yellowtail jack are best thought of as generalist, opportunistic predators (Baxter, 1960). Our analysis confirms this notion, although several prey species made up the majority of all contents of stomachs from fish sampled in the SCB. By functional group, coastal pelagic fish species, including Pacific sardine, northern anchovy, Pacific chub mackerel, and jack mackerel, accounted for the largest percentage of stomach contents $(61.5 \%)$. However, by species, the pelagic red crab was the most prevalent single species across all stomachs sampled (22.7\%), and crabs of this species were found in fish from all sampled areas in the SCB.

The primary driver of diet variation in sampled yellowtail jack was body size, with the number of both individual prey species and functional groups consumed increasing with body size. This relationship, combined with size-mediated increases in $\delta^{15} \mathrm{~N}$ enrichment and the lack of spatial variation in the proportion of consumed functional groups, indicates that the dominant trend in diet composition is ontogenetic rather than spatial. The case for such ontogenetic shifts is further supported by size-dependent differences in diet composition, with the diet of fish larger than $61 \mathrm{~cm} \mathrm{FL}$ being proportionally more diverse than that of smaller fish (Fig. 2). In addition to an ontogenetic shift in diet, these results could also reflect an ontogenetic shift in habitat, given that yellowtail jack are assumed to transition from offshore (less diverse) habitats to inshore (more diverse) habitats as they age (Horn and Allen, 1978).

\section{El Niño conditions and fishery-dependent sampling: effects on assumed spatial diet patterns}

The prevalence of pelagic red crab in the diet of yellowtail jack reflects the period in which we sampled because early 2014 through late 2016 were anomalously warm in the SCB because of the confluence of strong El Niño conditions and the anomaly in the northeast Pacific Ocean called the blob (Bond et al., 2015). The presence of pelagic red crab in the SCB is a classic biological indicator of El Niño because they usually occur significantly farther south in more tropical waters but are advected northward during El Niño episodes (Lluch-Belda et al., 2005).

Although traditionally thought of as an offshore pelagic species, the pelagic red crab was widespread throughout the SCB for the majority of the sampling period as well as physically observed at practically every (inshore and offshore) sampling location (senior author, personal observ.). In addition to a lack of temporal variation in their presence, the ubiquitousness of pelagic red crab further confounded attempts to infer spatial patterns in the diet of yellowtail jack. Therefore, for yellowtail jack collected during 2014-2017, neither presence in stomachs nor isotopic signatures of pelagic red crab should be assumed to indicate necessarily that the fish in question was feeding in a pelagic habitat (e.g., Madigan et al., 2018), given the ubiquity of these crabs across habitat types during this time.

\section{Levels of $\delta^{15} \mathrm{~N}$ and $\delta^{13} \mathrm{C}$ : effects on body size}

We found no significant regional differences in $\delta^{15} \mathrm{~N}$ or $\delta^{13} \mathrm{C}$ levels in samples of bulk white muscle; however, both $\delta^{15} \mathrm{~N}$ and $\delta^{13} \mathrm{C}$ track with body size and $\delta^{15} \mathrm{~N}$ levels increase with increasing body size. The effect of size on $\delta^{15} \mathrm{~N}$ was unsurprising, given that larger fish feed on a wider variety of prey, a finding supported by stomach content analysis. Levels of $\delta^{13} \mathrm{C}$ also increase with body size, however, only in fish collected inshore. Offshore fish showed no sizemediated variation in $\delta^{13} \mathrm{C}$. Such size-mediated increases can indicate trophic partitioning within a population (Post, 2003). Considering that the difference in $\delta^{15} \mathrm{~N}$ values between fish that were the most and least enriched was more than $3 \%$ ( $13.00 \%$ versus $\left.18.34 \% \circ \delta^{15} \mathrm{~N}\right)$, and assuming a consistent prey base, large $(>90 \mathrm{~cm}$ FL) yellowtail jack probably feed between 1 and 2 estimated trophic levels above their smallest conspecifics (Post, 2002).

\section{Size-mediated effects: evidence of ontogenetic shift in habitats}

Anglers and researchers have long assumed that yellowtail jack in the SCB shift from offshore to inshore environments as they grow, assumptions supported by work on congeners in Japan and in Australia and New Zealand (Sakakura and Tsukamoto, 1998; Kasai et al., 2000). Within the SCB, aside from recent isotopic analysis (Madigan et al., 2018), the case for such an ontogenetic shift has been based largely on anecdotal reports from commercial and recreational anglers. We observed that most of the biological variation in yellowtail jack from the SCB correlates with body size, not collection location. In addition, $\delta^{15} \mathrm{~N}$ and $\delta^{13} \mathrm{C}$ enrichment, stomach contents, and diet diversity, all vary significantly with body size. Results of previous tagging work (Baxter, 1960; Gillanders et al., 2001; senior author, unpubl. data) indicate that broad-scale movements are size dependent as well, given that intermediate-sized fish (60-90 cm FL) were recaptured significantly farther from tagging locations than either small (0-60 cm FL) or large (>90 cm FL) yellowtail jack (10-100 km versus $100-1000 \mathrm{~km})$. When viewed in concert, these factors indicate a likely shift from offshore to inshore habitat once fish are sexually mature.

Levels of $\delta^{13} \mathrm{C}$ also point to a potential size at which habitat transition occurs because $\delta^{13} \mathrm{C}$ values overlap for inshore and offshore yellowtail jack only at sizes of approximately $55-70 \mathrm{~cm}$ FL (the approximate size of sexual maturity). The divergence in $\delta^{13} \mathrm{C}$ levels indicates a shift in consumption of prey from those exhibiting carbon signatures in line with pelagic environments to species associated with inshore kelp forests (Glaser et al., 2015; Koenigs et al., 2015). Levels of $\delta^{13} \mathrm{C}$ enrichment that indicate an increase in trophic level also support the notion of an ontogenetic transition from offshore to inshore habitats. Offshore, pelagic habitats are generally more depleted in $\delta^{15} \mathrm{~N}$ in comparison with inshore habitats influenced by seasonal upwelling and other sources of nitrogen (Lajtha and Michener, 1994). Considering potentially lengthy isotopic turnover times in muscle tissue (MacNeil et al., 2006; Madigan et al., 2012), 
and the robust swimming ability of yellowtail jack (Clark and Seymour, 2006), the lower $\delta^{15} \mathrm{~N}$ values in small $(<60 \mathrm{~cm}$ FL) yellowtail jack from the inshore region could be a remnant from their juvenile phase in the pelagic environment. Conversely, higher $\delta^{15} \mathrm{~N}$ values in large (>90 cm FL) yellowtail jack collected offshore could indicate relatively brief offshore forays, perhaps for spawning.

\section{Life history in the context of changing oceans}

The results of our study update our understanding of the basic life history for a highly popular, yet under-studied and under-managed game fish. Our results point to yellowtail jack in the SCB as one contiguous population with consistent ontogenetic variation in diet, trophic position, and growth rate and indicate that global climate events affect yellowtail jack in the SCB. Whether by forcing northward range expansion, increasing fishing mortality, or changing available prey assemblages, the anomalously warm blob and El Niño conditions within the SCB during our sampling period influenced our results and confounded efforts to discern potential regional differences. Coincidentally, sampling for the sole previous analysis of the life history of yellowtail jack also occurred during extended positive and neutral El Niño periods. Interestingly, despite massive increases in anthropogenic effects along the coastlines of the SCB and northern Baja California since yellowtail jack were previously studied in the mid-1950s, most life history characteristics remain similar. Ultimately, the effects of increasing environmental variability and ocean warming on life history, abundance, and local and regional movement patterns of this species are not yet understood and require further investigation before being taken into account for potential management decisions.

\section{Acknowledgments}

The work described here was funded through a Mia J. Tegner Research Fellowship and a University of California Natural Reserve System Research Fellowship. We thank the captains and crews of the FV San Diego, FV New Lo-An, FV Outer Limits, and numerous other sportfishing operations in southern California and Mexico for facilitating sample collection. Thanks to Y. Eynaud and P. Kuriyama for their analytical and statistical assistance and to J. Holdsworth and C. Walsh for age estimation insight.

\section{Literature cited}

Abbink, W., A. B. Garcia, J. A. C. Roques, G. J. Partridge, K. Kloet, and O. Schneider.

2012. The effect of temperature and $\mathrm{pH}$ on the growth and physiological response of juvenile yellowtail kingfish Seriola lalandi in recirculating aquaculture systems. Aquaculture 330-333:130-135. Crossref
Barott, K. L., G. J. Williams, M. J. A. Vermeij, J. Harris, J. E. Smith, F. L. Rohwer, and S. A. Sandin.

2012. Natural history of coral-algae competition across a gradient of human activity in the Line Islands. Mar. Ecol. Prog. Ser. 460:1-12. Crossref

Baxter, J. L.

1960. A study of the yellowtail Seriola dorsalis (Gill). Calif. Dep. Fish Game, Fish Bull. 110, 81 p.

Beamish, R. J., and D. A. Fournier.

1981. A method for comparing the precision of a set of age determinations. Can. J. Fish. Aquat. Sci. 38:982-983. Crossref

Bellquist, L., and B. X. Semmens.

2016. Temporal and spatial dynamics of 'trophy'-sized demersal fishes off the California (USA) coast, 1966 to 2013. Mar. Ecol. Prog. Ser. 547:1-18. Crossref

Ben-Aderet, N. J.

2017. The biology of yellowtail (Seriola lalandi) in the Southern California Bight: spatial insights from recreational catch records, tagging, and life-history characteristics. Ph.D. diss., 124 p. Univ. Calif., San Diego, San Diego, CA.

Bograd, S. J., and R. J. Lynn.

2003. Long-term variability in the Southern California Current System. Deep Sea Res., II 50:2355-2370. Crossref

Bond, N. A., M. F. Cronin, H. Freeland, and N. Mantua.

2015. Causes and impacts of the 2014 warm anomaly in the NE Pacific. Geophys. Res. Lett. 42:3414-3420. Crossref

Champion, C., A. J. Hobday, X. Zhang, G. T. Pecl, and S. R. Tracey.

2018. Changing windows of opportunity: past and future climate-driven shifts in temporal persistence of kingfish (Seriola lalandi) oceanographic habitat within southeastern Australian bioregions. Mar. Freshw. Res. 70:33-42. Crossref

Chang, W. Y. B.

1982. A statistical method for evaluating the reproducibility of age determination. Can. J. Fish. Aquat. Sci. 39:12081210. Crossref

Chavez, F. P., C. A. Collins, A. Huyer, and D. L. Mackas.

2002. El Niño along the west coast of North America. Prog. Oceanogr. 54:1-5. Crossref

Choat, J. H., and L. M. Axe.

1996. Growth and longevity in acanthurid fishes; an analysis of otolith increments. Mar. Ecol. Prog. Ser. 134:15-26. Crossref

Clark, T. D., and R. S. Seymour.

2006. Cardiorespiratory physiology and swimming energetics of a high-energy-demand teleost, the yellowtail kingfish (Seriola lalandi). J. Exp. Biol. 209:3940-3951. Crossref

Clothier, C. R.

1950. A key to some Southern California fishes based on vertebral characters. Calif. Dep. Fish Game, Fish Bull. 79, 83 p.

Dotson, R. C., and R. L. Charter.

2003. Trends in the southern California sport fishery. CalCOFI Rep. 44:94-106.

Francis, M. P., J. McKenzie, and C. Ó Maolagáin.

2014. Attempted validation of the first annual growth zone in kingfish (Seriola lalandi) otoliths. N. Z. Fish. Assess. Rep. 2014/08, 19 p. Minist. Prim. Ind., Wellington, New Zealand. [Available from website.]

Gillanders, B. M., D. J. Ferrell, and N. L. Andrew.

1999. Aging methods for yellowtail kingfish, Seriola lalandi, and results from age- and size-based growth models. Fish. Bull. 97:812-827.

2001. Estimates of movement and life-history parameters of yellowtail kingfish (Seriola lalandi): how useful are data from a cooperative tagging programme? Mar. Freshw. Res. 52:179-192. Crossref 
Glaser, S. M., K. E. Waechter, and N. C. Bransome.

2015. Through the stomach of a predator: regional patterns of forage in the diet of albacore tuna in the California Current System and metrics needed for ecosystem-based management. J. Mar. Syst. 146:38-49. Crossref

Hobday, A. J., and K. Evans.

2013. Detecting climate impacts with oceanic fish and fisheries data. Clim. Chang. 119:49-62. Crossref

Holdsworth, J. C., J. R. McKenzie, C. Walsh, K. M. van der Straten, and C. Ó Maolagáin.

2013. Catch-at-age of yellowtail kingfish (Seriola lalandi) caught by recreational fishers in KIN 1, New Zealand. N. Z. Fish. Assess. Rep. 2013/3, 28 p. Minist. Prim. Ind., Wellington, New Zealand. [Available from website.]

Horn, M. H., and L. G. Allen.

1978. A distributional analysis of California coastal marine fishes. J. Biogeogr. 5:23-42. Crossref

Jackson, G. A.

1986. Physical oceanography of the Southern California Bight. In Plankton dynamics of the Southern California Bight, vol. 15 (R. W. Eppley, ed.), p. 13-52. Springer-Verlag, New York.

Kasai, A., W. Sakamoto, Y. Mitsunaga, and S. Yamamoto.

2000. Behaviour of immature yellowtails (Seriola quinqueradiata) observed by electronic data-recording tags. Fish. Oceanogr. 9:259-270. Crossref

Kimura, D. K.

1980. Likelihood methods for the von Bertalanffy growth curve. Fish. Bull. 77:765-776.

Kimura, D. K., R. R. Mandapat, and S. L. Oxford.

1979. Method, validity, and variability in the age determination of yellowtail rockfish (Sebastes flavidus), using otoliths. J. Fish. Res. Board Can. 36:377-383. Crossref

Koenigs, C., R. J. Miller, and H. M. Page.

2015. Top predators rely on carbon derived from giant kelp Macrocystis pyrifera. Mar. Ecol. Prog. Ser. 537:1-8. Crossref

Lajtha, K., and R. H. Michener (eds.).

1994. Stable isotopes in ecology and environmental science, 316 p. Blackwell Sci. Publ., Oxford, UK.

Lluch-Belda, D., D. B. Lluch-Cota, and S. Lluch-Cota.

2005. Changes in marine faunal distributions and ENSO events in the California Current. Fish. Oceanogr. 14:458467. Crossref

Love, M. S.

2006. Subsistence, commercial, and recreational fisheries. In The ecology of marine fishes: California and adjacent waters (L. G. Allen, D. J. Pondella, and M. H. Horn, eds.), p. 567-594. Univ. Calif. Press, Berkeley, CA.

Lowry, M. S.

2011. Photographic catalog of California marine fish otoliths: prey of California sea lions (Zalophus californianus). NOAA Tech. Memo. NMFS-SWFSC-483, 250 p.

MacNeil, M. A., K. G. Drouillard, and A. T. Fisk.

2006. Variable uptake and elimination of stable nitrogen isotopes between tissues in fish. Can. J. Fish. Aquat. Sci. 63:345-353. Crossref

Madigan, D. J., S. Y. Litvin, B. N. Popp, A. B. Carlisle, C. J. Farwell, and B. A. Block.

2012. Tissue turnover rates and isotopic trophic discrimination factors in the endothermic teleost, Pacific bluefin tuna (Thunnus orientalis). PLoS ONE 7(11):e49220. Crossref

Madigan, D. J., O. E. Snodgrass, and N. S. Fisher.

2018. From migrants to mossbacks: tracer- and tag-inferred habitat shifts in the California yellowtail Seriola dorsalis. Mar. Ecol. Prog. Ser. 597:221-230. Crossref
Manooch, C. S., III, and J. C. Potts.

1997. Age, growth, and mortality of greater amberjack, Seriola dumerili, from the U.S. Gulf of Mexico headboat fishery. Bull. Mar. Sci. 61:671-683.

Martinez-Takeshita, N., C. M. Purcell, C. L. Chabot, M. T. Craig, C. N. Paterson, J. R. Hyde, and L. G. Allen.

2015. A tale of three tails: cryptic speciation in a globally distributed marine fish of the genus Seriola. Copeia 103:357-368.

McKenzie, J., M. Smith, T. Watson, M. Francis, C. Ó Maolagáin, C. Poortenaar, and J. Holdsworth.

2014. Age, growth, maturity and natural mortality of New Zealand kingfish (Seriola lalandi lalandi). N. Z. Fish. Assess. Rep. 2014/03. Minist. Prim. Ind., Wellington, New Zealand. [Available from website.]

Miller, P. A., A. J. Fitch, M. Gardner, K. S. Hutson, and G. Mair.

2011. Genetic population structure of yellowtail kingfish (Seriola lalandi) in temperate Australasian waters inferred from microsatellite markers and mitochondrial DNA. Aquaculture 319:328-336. Crossref

Nelson, G. A.

2018. Fishmethods: fishery science methods and models. $\mathrm{R}$ package, vers. 1.11-0. [Available from website.]

Ogle, D. H.

2018. FSA: fisheries stock analysis. $\mathrm{R}$ package, vers. 0.8.20. [Available from website.]

Pauly, D.

1980. On the interrelationships between natural mortality, growth parameters, and mean environmental temperature in 175 fish stocks. ICES J. Mar. Sci. 39:175-192. Crossref

Pearcy, W. G.

2002. Marine nekton off Oregon and the 1997-98 El Nino. Prog. Oceanogr. 54:399-403. Crossref

Perry, A. L., P. J. Low, J. R. Ellis, and J. D. Reynolds.

2005. Climate change and distribution shifts in marine fishes. Science 308:1912-1915. Crossref

Peterson, B. J., and B. Fry.

1987. Stable isotopes in ecosystem studies. Annu. Rev. Ecol. Syst. 18:293-320.

Post, D. M.

2002. Using stable isotopes to estimate trophic position: models, methods, and assumptions. Ecology 83:703-718. Crossref

2003. Individual variation in the timing of ontogenetic niche shifts in largemouth bass. Ecology 84:1298-1310. Crossref

Premachandra, H. K. A., F. Lafarga-De la Cruz, Y. Takeuchi, A. Miller, S. Fielder, W. O'Connor, C. H. Frère, N. H. Nguyen, I. Bar, and W. Knibb.

2017. Genomic DNA variation confirmed Seriola lalandi comprises three different populations in the Pacific, but with recent divergence. Sci. Rep. 7:9386. Crossref

Quinn, T. J., II, and R. B. Deriso.

1999. Quantitative fish dynamics, 542 p. Oxford Univ. Press, New York.

$\mathrm{R}$ Core Team.

2018. R: a language and environment for statistical computing. R Foundation for Statistical Computing, Vienna, Austria. [Available from website, accessed March 2018.]

Sakakura, Y., and K. Tsukamoto.

1998. Social rank in schools of juvenile yellowtail, Seriola quinqueradiata. J. Appl. Ichthyol. 14:69-73. Crossref

Schiff, K. C., M. J. Allen, E. Y. Zeng, and S. M. Bay. 2000. Southern California. Mar. Pollut. Bull. 41:76-93. Crossref Shiraishi, T., S. Ohshimo, and R. Yukami.

2010. Age, growth and reproductive characteristics of gold striped amberjack 1 Seriola lalandi in the waters off western Kyushu, Japan. N. Z. J. Mar. Freshw. Res. 44:117-127. Crossref 
Sicuro, B., and U. Luzzana.

2016. The state of Seriola spp. other than yellowtail (S. quinqueradiata) farming in the world. Rev. Fish. Sci. Aquacult. 24:314-325. Crossref

Smith-Vaniz, W. F.

1986. Carangidae. In Smiths' sea fishes (M. M. Smith and P. C. Heemstra, eds.), p. 638-661. Springer-Verlag, Berlin, Germany.

Smith-Vaniz, W. F., J. C. Quéro, and M. Desoutter.

1990. Carangidae. In Check-list of the fishes of the eastern tropical Atlantic (CLOFETA), vol. 3 (J. C. Quéro, J. C. Hureau, C. Karrer, A. Post, and L. Saldanha, eds.), p. 729-755. Natl. Board Sci. Tech. Res. (JNICT), Lisbon, Portugal.

Stewart, J.

2011. Evidence of age-class truncation in some exploited marine fish populations in New South Wales, Australia. Fish. Res. 108:209-213. Crossref

Stewart, J., D. J. Ferrell, and B. van der Walt.

2004. Sizes and ages in commercial landings with estimates of growth, mortality and yield per recruit of yellowtail kingfish (Seriola lalandi) from New South Wales, Australia. Mar. Freshw. Res. 55:489-497. Crossref

Stuart-Smith, R. D., N. S. Barrett, C. M. Crawford, S. D. Frusher, D. G. Stevenson, and G. J. Edgar.

2008. Spatial patterns in impacts of fishing on temperate rocky reefs: are fish abundance and mean size related to proximity to fisher access points? J. Exp. Mar. Biol. Ecol. 365:116-125. Crossref
Sumida, B. Y., H. G. Moser, and E. H. Ahlstrom.

1985. Descriptions of larvae of California yellowtail, Seriola lalandi, and three other carangids from the eastern tropical Pacific: Chloroscombrus orqueta, Caranx caballus, and Caranx sexfasciatus. CalCOFI Rep. 26:139-159.

Sutton, S. G., and R. B. Ditton.

2005. The substitutability of one type of fishing for another. North Am. J. Fish. Manage. 25:536-546. Crossref

Tian, Y., H. Kidokoro, T. Watanabe, Y. Igeta, H. Sakaji, and S. Ino. 2012. Response of yellowtail, Seriola quinqueradiata, a key large predatory fish in the Japan Sea, to sea water temperature over the last century and potential effects of global warming. J. Mar. Syst. 91:1-10. Crossref

Vergani, M., E. M. Acha, J. M. D. de Astarloa, and D. Giberto. 2008. Food of the yellowtail amberjack Seriola lalandi from the south-west Atlantic. J. Mar. Biol. Assoc. 88:851-852. Crossref

von Bertalanffy, L.

1938. A quantitative theory of organic growth (Inquiries on growth laws. II). Hum. Biol. 10:181-213.

Zgliczynski, B. J.

2015. The direct and indirect effects of predators on coral reef fish assemblages. Ph.D. diss., 181 p. Univ. Calif., San Diego, San Diego, CA.

Zgliczynski, B. J., G. J. Williams, S. L. Hamilton, E. G. Cordner,

M. D. Fox, Y. Eynaud, R. H. Michener, L. S. Kaufman, and

S. A. Sandin.

2019. Foraging consistency of coral reef fishes across environmental gradients in the central Pacific. Oecologia 191:433-445. Crossref 